\title{
The Challenge of Military Police Training in the State of Rio de Janeiro: Utopia or Real Possibility?
}

\author{
Marcio Pereira Basilio ${ }^{1,2, *}$, Vicente Riccio ${ }^{3}$ \\ ${ }^{1}$ Department of Production Engineering, Federal Fluminense University, Brazil \\ ${ }^{2}$ General Staff, Military Police of the State of Rio de Janeiro, Brazil \\ ${ }^{3}$ Department of Public Law Material, Federal University of Juiz de Fora, Brazil
}

Copyright $\bigcirc 2017$ by authors, all rights reserved. Authors agree that this article remains permanently open access under the terms of the Creative Commons Attribution License 4.0 International License

\begin{abstract}
This study represents research that sought to understand the formative process of public security professionals in the state of Rio de Janeiro, Brazil, from the perspective of the military police officer. Training is the systematic process of orienting the comportment of people toward organisational directives. In the case of public security organisations, these objectives adhere to the objectives of the security policy promoted by the government. The relevance of this study resides in its academic consideration of the model of military police training and its influence on the implementation of public security policy and how it compromises its results. Thus, the research is predominantly qualitative in character. It is also an exploratory study that seeks to understand the police training process for the Military Police of the State of Rio de Janeiro from the perspective of the military police officer, a field in which there is little accumulated and systematic knowledge in Brazil. The research methodology consists of documentary and bibliographic fieldwork. Twenty-four semi-structured interviews with military police officers were conducted and processed using content analysis. The results were classified into five categories. The results reveal that, from the perspective of the interviewees, the training course for soldiers should join theory and practice, undergo investments in infrastructure, include trained teachers, and allow for the broaching of topics related to the complexity of police service, thereby reducing militarism. In this regard, this study opens up new questions: Why this type of training? What is the underlying logic of the security policy in Rio de Janeiro?
\end{abstract}

Keywords Public Security, Police Training, Brazil, Government

\section{Introduction}

The shift in focus to the performance of police officers depends in large part on effective training. The training process is also important because it seeks to convey information as well as to develop skills, attitudes, and concepts. In a repressive security policy, police officers are trained to act in a reactive manner. However, in a policy based on management and prevention, police officers are trained to react proactively toward the resolution of problems that emerge in everyday life.

The process of training should make the necessary knowledge available to police officers to carry out their daily activities [1]. However, the nature of police work is complex. In a democratic society, police officers should be proactive in seeking to act to solve problems. Thus, the responsibilities of the job in police work are amplified, and its complexity emerges in this context. Therefore, the formative process should include knowledge of the legal, social, and psychological order, as well as of the expertise inherent to police activity.

Understanding the daily activities of the police is the first step toward an analysis of the efficiency of a police training programme. Police training should be intimately related to the service to be performed in society. Therefore, it is important to contextualise police work within democratic society. The autonomy of police action, in the social context, is intrinsically related to the conceptual instrumentalisation that the public security officer possesses.

Therefore, this study aims to comprehend the public security officer training process in the state of Rio de Janeiro. The research was guided by the following question: What is the perception of the police in relation to the training received in the police academy in function of the daily activities that they perform in the police service? It is also an exploratory study that seeks to understand the police training process for the Military Police of the State of Rio de Janeiro (Polícia Militar do Estado do Rio de Janeiro - PMERJ) from the perspective of the military police officer, a field in which there is little accumulated and systematic knowledge in Brazil. The research 
methodology consists of documentary and bibliographic fieldwork. Because the author has been a senior officer of the institution since 1990, participant observation is also involved.

The fieldwork consisted of the performance of semi-structured interviews with twenty-four military police officers. The interviews were transcribed and processed using, which is detailed in the body of work. The research is predominately qualitative in character. The study's findings paint a chaotic picture that delineates the training process of the Military Police of the State of Rio de Janeiro that tends toward inefficiency in cognitive construction, which is necessary for public security officers to address the complexity of their daily activity.

\section{Materials and Methods}

\subsection{The Nature of Police Work - Problems and Contradictions}

To understand the topic of military police training in the state of Rio de Janeiro, it is necessary to identify what duties, situations, and actions are involved in police service. Police training is not limited solely to analysing programmatic content, discussing working hours, and/or the methodologies employed but also includes aspects related to the society in which the police officers are inserted [2]. The training should prepare the officer to interact with the society from which he was recruited. Therefore, this section presents background information necessary for understanding the variables that are ever-present in police service.

According to Bayley [3], 'to define what police do is not a simple question, not only because it is difficult to insure permanent access to them, but also for intellectual reasons' (p.118). The taxonomy used by the author identifies three distinct ways to describe police activity, each from different information sources. Police work can refer to, first, that which the police officer is designated to do; second, to the situations which he or she has to address; third, the actions that he or she should take to address those situations.

Duties are organisational descriptions of what the police do - patrol, investigate, control traffic, advice and administer. Once staff patterns are normally archived, we can easily determine the proportion of personnel assigned to different activities. The greater the amount of formal specialisation within police organisations, the easier this analysis becomes. At the same time, duty is a very crude indicator of what the police do. Bayley asserts that the duty most commonly assigned to police officers throughout the world is patrolling. However, patrolling is a multifaceted activity. Patrol officers are "jacks-of-all-trades". The English astutely refer to them as "general duty officers". To a large extent, this is because officers with any duty, not only patrolling, can do other things associated with other duties, as suggested by the following [4]:

"Transit police also patrol, patrol officers control transit, detectives advise youths, juvenile delinquency officers collect evidence about crimes, riot police also guard public buildings, and all do a lot of administrative work"( pp. 122-123).

Police work is also commonly described in terms of the situations in which the police become involved, including crimes in progress, domestic disputes, missing children, automobile accidents, suspicious persons, alleged burglaries, public disturbances, and unnatural deaths. In these cases, the nature of police work is defined by that which police officers must address.

Bayley [3] asserts that "the work can be described in terms of actions executed by police during situations, such as arresting, reporting, reassuring, advising, providing first aid, counselling, mediating, disrupting, threatening, citing and so on"(p.121). In these cases, the work of police officers is that which they do in the situations they encounter.

Despite the conceptual distinctions among duties, situations, and outcomes, they are interdependent. In other words, the structure of duties affects the types of situation in which a police officer becomes involved; the situations influence the spectrum of likely outcomes; the results shape the situations that the public is encouraged to report to the police; and the situations partly determine the formal duties within the police organisation.

To understand the nature of police work, one must first infer something regarding the social system in which the police officer is inserted. Kant de Lima [5] exhibits two models of society, which he denominated "parallelepiped" and "pyramidal". In the first model, the rules that regulate social conflicts have a generic aspect. That is, their effects are distributed equitably throughout society. The social class that an individual belongs to does not matter, the law applies to him or her as well. In the second model, the rules of the utilisation of public space are universal but not general. That is, although the laws are the same for everyone, they do not apply to everyone in the same way but rather in a manner particular to each person. Consequently, police action in these models is differentiated.

Kant de Lima [5] asserts that the police, ultimately, are the designated institution to empirically enforce, in both models, the rules of the utilisation of public space. Regarding the first model, the police will be the legitimate force for that which the authors call to enforce the law. It is noteworthy. However, that the rule that is being enforced finds support in the idea that it was consensual and legitimately designed to preserve a certain group's use of a certain public space. Thus, the legitimacy of police action does not reside with the state but in collective government. In this conception, "police have autonomy - and the subsequent responsibility - to negotiate the utilisation of 
the spaces, to a certain point: if the public space is a space negotiated collectively, it falls to the police to reproduce, in their administration, the processes of negotiation of divergent interests" (p. 205). The police, therefore, are neither neutral nor impartial.

With regard to the pyramidal model, Kant de Lima [5] stresses that the role of the police is very different from the previous model. The appropriation of public space in a particularised way by the state, by definition, takes an exclusionary form. In this model, conflicts should be minimised or, when conciliation is impossible, strongly reprimanded and terminated.

In the pyramidal model, the police do not just limit themselves to the explicit enforcement of the law. In this case, [5]"the function of the police is characterised, thus, to be eminently interpretive departing not only from the facts, but mainly the deciphering of the place of each of the parties in the social structure, so as to make the correct application of the rules of unequal treatment to the structurally dissimilar" (pp.206-207).

In this conception, according to the author, both the state and the police are defined as institutions separate from and external to the citizenry, whom they must not only control but also keep in check and suppress. Police action is characterised by the suspicion of disobeying the rules. Police activities do not act as mediators in conflict but instead as an intermediary authority the interpretation of which promotes the cessation or punishment of conflict, not its resolution.

The nature of police work is related to the tensions created by social relations. Police organisations act in a way to intervene and regulate interactions in society. The form that the action takes is directly related to the government regime under which said institution will be held accountable. Bittner [6] states that "the role of police is to confront all types of human problems when their solutions have the power to require the use of force at the time they are occurring" (p. 136). In his analysis, the author understands police work as being oriented toward risk, danger, violence, the dominion of chaos, violence, uncertainty, and despair. The author broadens the discussion of police work by stating that policing is a complex occupation that encounters serious problems. Therefore, it requires knowledge and skill. However, the most important thing is that those who practice it are imbued with considerable power to use force when necessary. In Bittner's [6] vision, policing is not a technique. On the contrary, it makes great demands in terms of experience and judgement, as asserted by Lipsky [7]. Experience is the accumulated knowledge on which the understanding of needs and practical possibilities is based. The author asserts [6]:

"in their day-to-day work, police frequently deal with subjects that others respond to with fear, anger, or disgust. It could be said that police work is to proceed methodically on the occasions that the standard would be an impulsive reaction". (p. 270).

The author observed that most police work is performed by individual police officers or by teams of two police officers. Thus, police officers depend mainly on their own knowledge, skills, and judgements and should be prepared to finish what they start by themselves.

In modern society, Bittner [6] identifies three expectations that define the function of the police: "First, it is expected that police will do something regarding any problem where they are called to help; second, it is expected that they will face problems at any place or at any time in which they occur; and third, it is expected that police will prevail in everything they do and not retreat in the face of opposition" (pp. 314-315).

Bittner [6] identifies two inadequacies of police work. The first is related to the problem of legality, which regards compliance with the codified regulatory scheme. This problem is related to the evolution of social dynamics; some behaviour can be regulated, whereas others cannot, or have not been regulated yet. The second problem is related to the training of the workforce; it involves the maintenance of minimally acceptable levels of wise, skilful, and judicious performance.

Monjardet [8] questions Bittner's idea that the police are nothing more than society's distribution mechanism of power justified by the situation. Thus, he makes an analogy and notes that "the police are a hammer" (pp. 21-22). As a tool, the hammer itself has no purpose; it serves the aims of whoever wields it. According to Monjardet, the police act in the same way: it is an instrument for the application of force over an object chosen by the person who commands it. Police are to serve [ancillaire] and receive their definition - in the sense of their role in social relations from that which commands them. Thus, they can serve the most diverse aims, from oppression in a totalitarian or dictatorial regime to the protection of liberties in a democratic regime. Sometimes the very same police may successfully serve opposing ends.

\subsection{Police Work in a Democratic Society}

In this section, we will take an approach to police performance in a democratic society whose origins are related to the individual needs of society. According to Sung [9], democratic norms, institutions, and practices, including those reported by the police, have evolved dramatically in democratic states. Due to this wave of democratisation, policing is recognised as a service of integration with society that allows for only the most qualified application of force. Because of enormous changes in the proportions and sophistication of crime in the recent decades [10], the police have undergone a rigorous review, and reform has become a top institutional policy priority. 
As a governmental agency in constant contact with the public as well as a coercive arm of the state, the police have been criticised and reinvented not only in democratising countries but also in countries with a liberal heritage and democratic government. The democratisation process is an endless institutional effort toward key ideals of democracy: liberty, equality, and fraternity. Thus, there is an expectation that the offshoots of these values can be integrated into the policies of democratic governments. Participation, equality, the consent to police, responsibility, the delivery of services, and mechanisms for review have been identified as necessary attributes and procedures for the police in a democratic society, according to Sung [9].

According to Rico [11], the police has always been an organ of the state, with their own characteristics that distinguish them from the other sectors that fall under the rubric of "the administration of justice", the mission of which has traditionally revolved around the application of laws and the maintenance of public order. Cerqueira [12] stresses that the police in a democratic regime should be representative, should correspond to public needs and expectations, and should be responsible. Being representative means that the police need to ensure that its officers are sufficiently representative of the community whom they serve. Minorities should be adequately represented inside policing institutions - by means of just and non-discriminatory recruitment policies and through policies designed to enable career advancement for members of these groups within the institutions. The second item relates to the needs and expectations of the population. From this perspective, the police need to be conscious of the needs and expectations of the population and conform to them. The third point listed, responsibility, is exercised in three main ways [12]:

"Legally - like all individuals and all institutions of Democratic Rule of Law, where constitutional order prevails, the police must be accountable to the law.

Politically - the police must be accountable to the population they serve, through the political and democratic institutions of government. Thus, their policies and practices to enforce the law and to maintain order undergo public scrutiny.

Economically - the police are responsible for the means with which they use the resources allocated to them. This goes beyond the scrutiny of their major police functions, and is another form of democratic control of the command, management and administration of a police institution". (p. 27).

Goldstein [13] offers a profound analysis of the fundamental questions that are at the heart of police reform and the improvement of police procedures and methods in contemporary democratic societies. The function of police in society, the discretionary power of the police, its commitment to democratic values, society's expectations concerning the police, the authority and resources available to the police, the criminal justice system, and the evaluation of the service provided by police to society are not only necessary in the fight against crime but also, and especially, in the struggle for the consolidation and improvement of democracy and the rule of law.

\subsection{Perspectives on Police Training}

Police training is the process by which organisations prepare people to address various social conflicts. Police work is complex, and, thus, it requires adequate and proper training. According to Ness [14], the function of police training is to empower the police officer for daily work. In another study, Marion [15] found that the duration of police training varies from one state to another; thus, it was found that some courses are conducted with a workload of 650 class hours, many police cadets complete basic training with 400 class hours, and, exceptionally, in the best training schools, the cadets complete basic training with 850 class hours. At the University Academy (UA) in the US state of Ohio, where the research was conducted, the students completed basic training with 543 class hours. One of the important points identified by Nancy Marion [15] regarded the environment of the academies. Many have a semi-military atmosphere, characterised by the use of physical exercise, additional work, and verbal harassment as punishment mechanisms for student inadequacies. However, the University Academy does not follow the noted practices, "the use of titles by the students in communication with their instructors is not required because respectful treatment is expected from the students", and the assignment of extracurricular duties is rare. Marion[15] also reported that the instructors are chosen based on their knowledge and teaching expertise, and personal qualities, such as camaraderie, maturity, enthusiasm, confidence and high self-esteem, are preferred. This is reflected in the instructional techniques that they adopt. Another important factor is the interactive aspect of instruction, which features student participation, and the adoption of the case-study method, the means by which theoretical knowledge is applied in practice.

Trautman [16] identified three types of learning that he considered essential for use in training academies that seek to perform effective training that leads to the proper and adequate formation of future police officers: Knowledge learning, skill learning, and attitude learning.

Knowledge acquisition, according to Marion [15], corresponds to the major part of content in training. In this phase, the students receive the theoretical content necessary for the adequate performance of their functions as police officers. In the UA, this phase corresponds to 345 total class hours, and disciplines such as civil responsibility, ethics, police history, laws, domestic violence, public relations, and victimology are taught. Skills development is the second type of learning identified by Trautman [16]. Students learn through movement repetition in order for these new skills to become natural to them. Frequently, practical field exercises or simulations are performed. 
During this phase, students have contact with the eminently practical disciplines related to the daily activities of police service, such as: shooting, personal defence, physical education, communication, hazardous materials (HAZMAT), traffic control, driving techniques, use of chemical weapons (OC spray, PR-24, ASP), investigation, and first aid. The third type of learning is behavioural. This training phase, according to Marion [15], is when students receive the information related to how they should act in the various day-to-day situations they will encounter as police officers, as well as their behaviour in society in general. Finally, it is noteworthy that the results of the study indicated that, in particular, the training programme developed by the UA provides students with the basic and necessary knowledge for initial performance for a career as a police officer. However, the UA still needs to undergo certain changes for continuous improvement.

Lord [17] conducted a study comparing the recruitment and the selection of police in Sweden with those of police in the United States, showing that, currently, the training of Swedish recruits is performed during two formal periods at the Swedish National Police Academy with 18 months of field training. The objective is to offer both theoretical and practical foundations. Training is fundamentally based on a democratic perspective and instils an understanding of human rights, democratic values, and of the importance of having a positive attitude with people. The training is organised to empower the student to acquire knowledge and skills and develop his or her critical capacity to assess different types of phenomena; training provides increased knowledge of international conditions and understanding of other cultures.

Engel et al, [18], in studying police reform in Northern Ireland in the transition to a democratic political model, focused on the importance of the inclusion of human rights classes in the training programme for the training of new police officers. The training of the Police Service of Northern Ireland (PSNI) is performed in four stages before the recruits enter service in the force. In the first stage, which lasts 10 weeks, the recruit is trained in operations first, in traffic and weapons. The second stage, also 10 weeks, takes place in units under the guidance of a tutor. In the third stage, the student serves under the direction of an experienced police officer for a period of 44 weeks. The fourth stage consists of a period of 44 weeks, and the students are evaluated before they enter the active service of the force. The curriculum of the training programme has nine central themes: 1) human rights: theory and practice; 2) diversity and the incorporation of equal opportunities for communities and ethnicities; 3) community policing; 4) community security; 5) problem resolution; 6) professional ethics; 7) values; 8) best practices; and 9) health and safety.

In their study, Roberg et al, [19] addressed a pertinent question for police training, education level. According to the authors, the debate over the university-level requirement for police service is nothing new. However, between 1950 and 1960, the minimum entrance requirement for police forces was a high school education or an equivalent diploma. At that time, police officers who possessed a bachelor's degree or were in university were frequently viewed with suspicion and distrust by their peers and supervisors. Two significant and inter-related events contributed to the growth of two- and four-year education for training programmes in the 1960s: the first event was the enormous increase in crime rates that began during the 1960s; and the second event was the increase of disturbances in the inner cities.

Regarding education level, Vickers [20] investigated the police service in Australia and found that the complexity of police work has increased a worldwide phenomenon. By contrast, the changes that have occurred require that the officers' standard operating procedures evolve. In this new context, police officers should understand and interpret the social, political, and historical facts of the new reality, and the skills necessary for doing so entail higher education. For Vickers [20], the aim of higher education is to liberate the mind, allowing people to depend on reason. Nevertheless, there is resistance within the Australian forces with regard to change, as Fitzgerald [21] states. Thus, a higher education requirement for police service is a factor that may allow for more tolerant and less authoritarian action.

\subsection{Training Course from the Trainer's Perspective - Fundamentals}

In this section, we will present to the reader the theoretical basis that served as the basis for the evaluation of the training course of police officers from the perspective of the student. In this sense, we resorted to the area of education, where it has a specific field of research about the learning environment of the classroom.

Fraser et al, [22] identified in their research work a considerable interest evident since the late 1960s in the conceptualization, assessment, and study of student perceptions of psychological characteristics of their classroom learning environment. According to them, [23, $24,25,26]$ have firmly established classroom environment as a thriving field of study. Fraser et al. [22] stated that, when used as criterion variables in prior curriculum evaluation research, student perceptions of classroom environment characteristics have differentiated revealingly, usefully, and appreciably between classrooms following alternative curriculum materials or instructional strategies $[27,28]$. In addition, other studies have established the criterion validity of classroom environment perceptions in differentiating between classrooms varying in class size [29], grade level [30], and subject matter [31], and between classrooms in five different types of schools (urban, rural, suburban, vocational, alternative) [32]. The strongest tradition in past research on classroom learning environment, however, according to Fraser et al. [22], has 
involved investigation of the predictive validity of student perceptions

According to Matos et al. [33] in the last three decades, the learning environment has been the object of study of countless research projects in a diversity of disciplines. Matos et al. [33] in his research identified the most recurrent subjects in this field as: analysis of students' cognitive performance [34]; Language and concept formation in science education [35]; Discursive dynamics present in experimental situations in school and non-school spaces [36]; Argumentative discursive practices of students of the didactic laboratory of physics [37]; Elaboration of didactic support material for teachers' pedagogical practices [38].

As recorded in the study developed by Matos et al. [33], the studies that approach the learning environment of the classroom present different modalities. According to Fraser [39], the most common modalities are: associations between the students' results and the learning environment of the classroom; Evaluation of educational innovations; Differences between the perceptions of the students and the instructor of the same classroom; Determinants of classroom learning; Use of qualitative research methods; And cross-cultural studies. According to the qualitative characteristic of the present study the qualitative methods will be deepened.

The combination of quantitative and qualitative methods is a recurrent practice in this field, according to Matos et al. [33]. Typically, qualitative methods are used in a complementary way. Interviews with students, teachers, school staff or family members, video recording of classrooms, observation of classes and use of field diaries are some examples pointed out by Matos et al. [33] in their research.

The work of Waldrip et al. [40] can exemplify the combination of quantitative and qualitative methods. The authors evaluated cultural factors that affect the learning environment of science students through the development and validation of the Cultural Learning Environment Questionnaire (CLEQ). This research aimed to study the learning environment of multicultural rooms. Interviews were used to understand how students interpreted each scale of the questionnaire, what they thought about the meaning of the sentences, the divergent perceptions within the same classroom.

Fraser [39] states that in relation to the use of quantitative and qualitative methods together, it is possible to emphasize that: the interviews and observation findings usually replicate the findings of the use of questionnaires in the learning environment; The information from the interviews with students helps to clarify their answers to the questionnaire; And interviews with teachers provide background information on the practical situation in classrooms. Matos et al. [33] states that the use of interviews provides valuable information about the context of the school.
Studies on the learning environment point to several advantages in using students' perceptions as an indicator of the quality of the classroom environment. As examples [41,42], students are directly involved in classroom activities and observe more typical teacher behavior than an outside observer; Students are more familiar with the idiosyncrasies of their teachers, which can be interpreted differently by an observer; Students are in a better position to judge certain aspects of teacher behavior, such as clarity of expression; The use of trained observers over a period of time is more expensive; The presence of observers can change what usually happens in the classroom.

\subsection{Methodology}

This is an exploratory study [43] that seeks to understand the PMERJ police training process from the perspective of the police officer, a field in which there is little accumulated and systematic knowledge in Brazil. The research methodology consists of documentary and bibliographic fieldwork. Because the author has been a senior officer of the institution since 1990, participant observation is also involved.

The collection of data, performed from April to May 2006, was composed of bibliographic and documentary research and interviews with workers in the industry. Documents inherent to the selection and training process of military police officers in the PMERJ were accessed. Books, theses, dissertations, national and international articles that discussed police training were reviewed. For the interviews, a script with semi-structured questions, which included topics concerning the vision and feelings of the military police officers in relation to the training process and its consequences for the activity of the institution, was used.

Twenty-four interviews, ranging in duration from twenty to forty-five minutes, were conducted, resulting in thirteen hours of recordings and more than two-hundred-and-fifty pages of transcriptions. All interviews were retained in full, respecting the "deviations" committed relative to the cultural norms of the Portuguese language. The names of those interviewed, their positions, or any other information that could identify them will not be disclosed. The interviews were conducted using a predetermined script, which was defined based on the research objectives. The interviewees were between twenty-two and thirty-six years of age, and they had from one to five years of PMERJ service, all of whom worked in the patrol radio policing service in the city of Niteroí. There were four women and twenty men. Fifty-seven percent finished high school, ten percent completed college, and thirty-three percent attended, but did not finish, college. Forty-three percent are married; seventy-three percent have a family income in the range of eight-hundred to one-thousand-two-hundred Brazilian reais. All are military police soldiers. 
The interviewees were selected and divided into categories based on their length of service in the military police. The first group was composed of military police in training; the second group was composed of soldiers who had between one and three years of service after finishing coursework; and the last group was composed of police officers who had between three and five years of service. This categorisation was based on the research objectives and the period from 2000 to 2005 .

The selection was also made geographically, focusing on the metropolitan region of Rio de Janeiro, which consists of the municipality of Niterói, among others. Policing in this region is the responsibility of the twelfth battalion of the military police. The choice of this operational unit for the selection of interviewees was made because it shared operational characteristics with the other units that operate in the capital and other municipalities in the state.

The police officers from the twelfth battalion of the military police were randomly chosen; the criterion of service time for the composition of the sample was respected. During the time in which the interviews were performed, the police officers in training found themselves interning in operational units and were inserted into the twelfth battalion of the military police. The interviewees granted voluntary consent. The conducting of the interviews respected the schedule that was established by the researcher and negotiated with the commander of the organisation under review to avoid administrative or operational disorder.

For better acquisition of data, all of the interviews were recorded and afterwards transcribed and analysed in accordance with the methodology described in this study. All interviews were retained in full, respecting the "deviations" committed relative to the cultural norms of the Portuguese language. The names of the interviewees, their positions, or any other information that could identify them will not be disclosed. The interviews were conducted according to a predetermined script, which was defined based on the research objectives.

Content analysis was conducted on the interviews.[43] "Content analysis is considered a technique for the processing of data that aims to identify what is being said about a particular topic" (p.15). Bardin [44] defines it as "a set of techniques for analysing communications to obtain, by systematic and objective procedures of description of message content, indicators (quantitative or otherwise) that allow the inference of knowledge regarding the conditions of production/reception (inferred variables) of these messages" (p.37). Content analysis includes both the analysis of documents and interviews because it consists of a tool for the analysis of what is being communicated in different media [44]: "Content analysis seeks to understand what is behind the words on which it leans" (p.38).

In this study, the approach to the text was thematic. The categorisation criterion adopted was semantic, and the unit of analysis was the paragraph. In this case, the significant paragraphs from the interviews were utilised to identify the elements of each category and their implication according to the research objectives established for this study [45].

\section{Results and Discussion}

From the answers provided by the military police officers, five categories were outlined: the gap between planning and execution; education, the instructors, and the investment in training; the police officer's qualifications; the police officer's perceptions regarding his or her training and the daily challenges of his or her duties; and possible improvements to the training process in the view of the police officer. The collected and categorised data were interpreted by means of qualitative procedures, and the results are presented in the following sections.

\subsection{The Gap between Planning and Execution}

The key element identified in this category is the deviation of purpose in police training. One of the points identified as critical is the utilisation of students in activities opposed to the training objectives, such as the performance of cleaning services, equipment maintenance services, painting, attendance at football games, and policing of the beach. What is clear is that the effectiveness of the students is used to overcome managerial deficiencies, such as the hiring of employees for cleaning and the maintenance of the barracks. Another point similarly critical of the training, according to the interviewees, is the fact that they are given insufficient knowledge of criminal, constitutional, and administrative law, the handling and use of weapons, and a basic approach that would enable them to exercise their functions. The gap between planning and execution is found when the formulation of a process is incongruent with reality, according to Basílio [46].

The central theme to be taken from the interviewees' testimony is the deviation of purpose in the course. Thus, a process of the devaluation of the public security professional in the state of Rio de Janeiro emerges. Consequently, the training course produces a professional cognitively and operationally deficiency for interacting with the emerging obstacles of the relational process of a democratic society [47-49].

\subsection{Education, the Instructors, and the Investment in Training}

In this category, two important aspects inherent to the development of the educational process of the PMERJ are addressed. The first concerns the training of the instructors. The instructor is an important link in the teaching-learning process because he or she is responsible for transmitting information and for illustrating the everyday events that, complementing theory, provide the student with a moment of reflection as to how one should act. The second aspect is 
related to the level of investment that the PMERJ makes regarding policing education and how the institution invests in infrastructure in the Garrison Training Centre (Centro de Formação de Praças - CFAP) and in the Operational Units, where the training courses for soldiers are held, according to Basílio [46].

Regarding the instructors, preparation is necessary for them to more effectively perform their jobs. The interviewees stressed that instructors should be well trained and possess extensive experience in law enforcement. This training will provide the development of practical exercises based on real events, which will provide students the opportunity to reflect and evaluate events without being under the pressure of the moment. Certainly, this is expected of a good instructor. Nonetheless, the interviews sketch a precarious picture regarding the training of the instructors.

Content analysis reinforces the impression that the military police are more concerned with quantity than quality. The interviews all show a common point, the lack of investment in infrastructure for soldier training courses, which is even more pronounced than the need to prepare the instructor to better teach at the institution. This perception can be better illustrated by taking into account the results of a survey carried out by the Public Finance Court of the State of Rio de Janeiro, in which it was obvious that the PMERJ does not conduct proper financial planning and budgeting. The priorities are established at whim in response to events. The effects of this practice can be seen in the reports in the category, which indicate that the training of soldiers is not a priority for the PMERJ [50].

\subsection{The Police Officer's Qualifications}

Currently in Brazil, graduation from high school is a necessary prerequisite for admission of candidates for the military police. However, a bibliographic review revealed that some countries in North America and in Europe require a college degree for entry into some police forces. In Brazil, this became a requirement for entry into the Federal Police. The intention would be to seek professionals possessing better knowledge, thus providing greater understanding and ability to address the various social conflicts within a framework of action as problem solvers rather than overcomers of obstacles.

Therefore, the interviewees were asked if the completion of a college degree for entry into the PMERJ would be important for the performance of police work. The interviewees answered that a college degree would not be appropriate because the organisational structure is not prepared for this change, according to Basílio [46].

However, it is found that, in general, the education level required currently has no direct relationship to any value added by police activity, even within the training programme. Reports indicate that police officers now perform the same activities that were previously performed by professionals with only a middle school level of education. In general, the interviewees believe that having knowledge is important. Yet, the structural problems faced by the military police make it impossible to require a college degree for admission as a military police soldier. Rather, the role of the police should be reconceptualised, the remuneration conditions revisited, and the men and women valued more so that such a change could result in the desired effect.

\subsection{The Police Officer's Perceptions Regarding His or Her Training and the Daily Challenges of His or Her Duties}

The content classified in this category synthesises police officers' perceptions regarding the training course. The central impression identified in the reports points to the sense of police unpreparedness. The majority did not feel prepared to confront the daily reality of police service in Rio de Janeiro. There were various reasons for this impression. The interviewees reported that they felt unprepared for firearm use because of the few shooting and armaments classes offered by the CFAP; some reported that they felt insecure in approaching certain segments of society because of a lack of knowledge of how address the situation; the police officers with more professional experience claimed that they learned more in the streets, in the day-to-day, with their direct superiors; others claimed that the CFAP focused on combat and not on how to handle social questions. In a way, this category reflects the image that police officers have of the training course, the image of a course that does not prepare them for the daily challenges of the profession.

In this category, there is a clear impression that the way the training is conducted does not prepare officers for the proper performance of police service in a democratic society. What is noteworthy is that police officers are being trained without the proper basic knowledge that will provide them with the necessary tools for the resolution of conflicts in everyday life in Rio de Janeiro, according Basílio [46].

\subsection{Possible Improvements to the Training Process in the View of the Police Officers}

In this last category, we sought to know what changes should be implemented to the training course of soldiers from the perspective of military police officers so that the training course matched the realities of their day-to-day duties.

Therefore, the content analysis of the interview reports reveals that a larger investment in infrastructure should be made to create a more adequate environment for the transmission of knowledge and the performance of practical exercises; the curriculum should be reformed, with emphasis on disciplines such as constitutional, 
criminal and administrative law, shooting and armaments, approach techniques, and personal defence, and an increase in workload should be contemplated; the training institutions should employ more qualified instructors; they should end the employment of students in general services, such as maintenance, painting, and weeding around the CFAP and other units; they should prioritise police education over militarism; and they should value education above all, according to Basílio [46].

From the perspective of the interviewees, the training course for soldiers should join theory and practice, undergo investments in infrastructure, include trained teacher, and allow for the broaching of topics related to the complexity of police service, thereby reducing militarism. This section dealt with the content analysis of the empirical data obtained by conducting twenty-four interviews with military police soldiers selected according to the methodology above.

\section{Conclusions}

The study aimed to discover the training process of the Military Police of the State of Rio de Janeiro from the perspective of the public security official, represented here by the military police officer.

Because the police are a product of society, the underlying logic in this case is the democratic rule of law. Policing organisations are essential in any system of government. However, their actions are distinct. In a democratic society, the police officer should act as a guarantor of citizens' rights. Therefore, the process of training the officials of public security should focus on this foundational idea. The proper preparation of the police officer directly results in the expansion of discretionary power, resulting in the reduction of inequalities pertinent to the police action of the state.

Thus, in a real and practical way, considering the training process from the perspective of the military police helps to understand the nuances of this process. Twenty-four military police officers were interviewed as the fieldwork, according to the methodology described above. Content analysis revealed a disturbing scenario regarding the training process. The results were classified into five categories and indicate that the training programme does not enable the public security professional to interact in the manner expected in a democratic society. In fact, the police officers revealed that, due to the lack of an adequate theoretical framework in the training programme, many felt insecure to perform police work effectively. Because of this deficiency in training, we believe that there is difficulty in operating in locations where the purchasing power is higher, which is not found in poor communities, according to the insights that emerge from the interviews.

Regarding the investment in and the training of instructors, the empirical data revealed that there was no investment in the infrastructure in the units where the training of military police is performed, for example, the lack of ammunition for shooting instruction. Regarding the training of instructors, it can be deduced that there is inadequate selection of instructors because many reports indicated that the instructor did not meet the task.

An important point that emerged in the testimonials was the deviation in the purpose of the course, in which students were used to perform tasks unrelated to the process of police training, such as general services and maintenance, to the detriment of instruction.

Thus, one can consider that the process of police training addressed here is full of inconsistencies regarding the theoretical framework investigated. While the authors recognise the complexity of police work, which requires an ever-greater understanding of social interactions, the interviews point in the opposite direction. We found that the Military Police of the State of Rio de Janeiro is being formed under the aegis of a militarised culture in which the smallest element within its hierarchy should only follow orders. The implication here is a distortion of the image of the public security professional, which, in response to the effects of social interactions, should examine the facts and exercise judgment. In other words, the exercise of discretion increases the spectral space for police action, thereby reducing social inequality.

Nevertheless, the proper use of discretion is conditioned by the agent's knowledge of his or her social role. It is exactly here where the temerity in military police training process is found. The interviews revealed deficiencies in both the structural nature and the constitution of the teaching body as well as in the dissemination of knowledge relevant to the preparation of a public security professional in a democratic system of government. Meanwhile, some authors point to the need for college education to enter the police forces of the countries that they examined because it enables a better understanding of social conflicts. In the present case, there is a long way to go. This begs the question of the desired profile for the police officer in Rio de Janeiro: a reactive police officer or a police officer who does not know how to proceed? Therefore, the restructuring of the police training process, integrated with the desired profile defined, should be considered, culminating in a process that changes the image of the police officer from a military police soldier to a technician in public security. This change should occur internally within the police organisation. Thus, one can conclude that the challenge of military police training in the state of Rio de Janeiro is not utopian but a real possibility, albeit one with a long way to go, which demands the joint efforts of the government, external control, police, and society.

\section{Acknowledgements}

A version of this study was presented at the $\mathrm{XX}$ International Congress of the CLAD on the Reform of the 
State and Public Administration, Lima, Peru, November 10 $-13.2015$

\section{REFERENCES}

[1] Riccio, V., \& Pereira Basílio, M. (November, 2006). As diretrizes curriculares da secretaria nacional de segurança pública (senasp) para a formação policial: a polícia militar do Rio de Janeiro e a sua adequação às ações federais [The curricular directives of the Brazilian secretariat of public security (senasp) for police training: the military police in Rio de Janeiro and their compliance with federal actions]. XI Congreso Internacional del CLAD sobre la Reforma del Estado y de la Administración Pública, Guatemala.

[2] Riccio, V., \& Pereira Basílio, M. (2007). As diretrizes curriculares da secretaria nacional de segurança pública (senasp) para a formação policial: a polícia militar do Rio de Janeiro e a sua adequação às ações federais [The curricular directives of the Brazilian Secretariat of public security (senasp) for police training: the military police in Rio de Janeiro and their compliance with federal actions]. In Roberto Salles, X. et al., A trajetória das políticas públicas no Brasil: uma reflexão multisetorial, pp. 212-241. Porto Alegre: Sagra Luzzatto.

[3] Bayley, D. H. (2002). Padrões de policiamento: uma análise internacional comparative ( $2^{\text {nd }}$ ed.) [Patterns of policing: a comparative international analysis]. Translated by René Alexandre Belmonte. Universidade de São Paulo, São Paulo.

[4] Martin, J. P., \& Wilson, G. (1969). The police: a study in manpower- the evolution of the service in England and Wales. London: Heinemann.

[5] Kant de Lima, R. (2002). Políticas de segurança pública e seu impacto na formação policial: considerações teóricas e propostas práticas [Polices of public security and their impact on police training: theoretical considerations and practical proposals]. In Zaverucha, J. (org), Políticas de Segurança pública: dimensão da formação e impactos sociais, pp. 199-219. Recife: Massangana.

[6] Bittner, E. (2003). Aspectos do trabalho policial [Aspects of police work]. Translated by Ana Luísa Amêndola Pinheiro. Universidade de São Paulo, São Paulo.

[7] Lipsky, M. (1983). Street-level bureaucracy: dilemmas of the individual in public services. Russell Sage Foundation, New York, NY.

[8] Monjardet, D. (2003). O que faz a polícia: sociologia da força pública [What does the police do: sociology of public force]. Translated by Mary Amazonas Leite de Barros. Universidade de São Paulo, São Paulo.

[9] Sung, H-E. (2006). Police effectiveness and democracy: shape and direction of the relationship. Policing: An International Journal of Police Strategies \& Management, 29(2), pp. 347-367.

[10] Bryett, K. (1999). The policing dynamic. Policing: An International Journal of Police Strategies \& Management, 22(1), pp. 30-44.

[11] Rico, J. M. (1992). Delito, insegurança do cidadão e polícia: novas perspectivas [Crime, citizen insecurity, and the police: new perspectives]. Translated by Mina Seinfeld de Carakushansky. Polícia Militar, Rio de Janeiro.

[12] Cerqueira, C. M. N. (1998). A polícia e os direitos humanos [Police and human rights]. Rio de Janeiro: Freitas Bastos.

[13] Goldstein, H. (2003). Policiando uma sociedade livre [Policing a free society]. Translated by Marcello Rollemberg; revised translation by Maria Cristina P. da Cunha Marques. Universidade de São Paulo, São Paulo.

[14] Ness, J. J. (1991). The relevance of basic law enforcement training- does the curriculum prepare recruits for police work: a survey study. Journal of Criminal Justice, 19(2), pp. 181-193.

[15] Marion, N. (1998). Police academy training: are we teaching recruits what they need to know? Policing: An International Journal of Police Strategies \& Management, 21(1), pp. 54-79.

[16] Trautman, N. E. (1986). Law enforcement training: a comprehensive guide for the development of effective law enforcement training programs. Springfield, IL: Charles C. Thomas, Publisher.

[17] Lord, V. B. (1998). Swedish police selection and training: issues from a comparative perspective. Policing: An International Journal of Police Strategies \& Management, 21(2), pp. 280-292.

[18] Engel, S. T., \& Burruss, G. W. (2004). Human rights in the new training curriculum of the police service of Northern Ireland. Policing: An International Journal of Police Strategies \& Management, 27(4), pp. 498-511.

[19] Roberg, R., \& Bonn, S. (2004). Higher education and policing where are we now? Policing: An International Journal of Police Strategies \& Management, 27(4), pp. 469-486.

[20] Vickers, M. H. (2000). Australian police management education and research: a comment from 'outside the cave'. Policing: An International Journal of Police Strategies \& Management, 23(4), pp. 506-524.

[21] Fitzgerald, G. E. (1989). Report of inquiry into possible illegal activities and associated police misconduct. Brisbane: State Government Printer.

[22] Fraser, B. J., \& Fisher, D.L. (1982). Evaluation studies: Predictive Validity of My Class Inventory. Studies in Educational. 8, (2). 129-140.

[23] Moos, R. H. (1979). Evaluating educational environments: Procedures, measures, findings and policy implications. San Francisco: Jossey-Bass.

[24] Walberg, H. J. (1979). Educational environments and effects: Evaluation, policy, and productivity. Berkeley, CA: McCutchan.

[25] Fraser, B. J. (1981). Learning environment in curriculum evaluation: A review. Evaluation in education: An international review series. London: Pergamon.

[26] Fraser, B. J., \& Walberg, H. J. (1981). Psychosocial learning environment in science classrooms: A review of research. Studies in Science Education, 8, 67-92. 
[27] Anderson, G. J., Walberg, H.J., \& Welch, W. W. (1969). Curriculum effects on the social climate of learning: A new representation of discriminant functions. American Educational Research Journal, 6, 315-327.

[28] Levin, T. (1980). Classroom climate as criterion in evaluating individualized instruction in Israel. Studies in Educational Evaluation, 6, 291-292.

[29] Walberg, H. J. (1969). Class size and the social environment of learning. Human Relations, 22, 465-475.

[30] Welch, W. W. (1979) Curricular and longitudinal effects on learning environments. In H.J. Walberg (Ed.), Educational environments and effects: Evaluation, policy, and productivity. Berkeley, CA: McCutchan.

[31] Hearn, J. C., \& Moos, R. H. (1978). Subject matter and classroom climate: A test of Holland's environmental propositions. American Educational Research Journal, 15, 111-124.

[32] Trickett, E. J. (1978). Toward a social-ecological conception of adolescent socialization: Normative data on contrasting types of public school classrooms. Child Development, 49, 408-414

[33] Matos, Daniel Abud Seabra, Cirino, Sérgio Dias, \& Leite, Walter Lana. (2008). Instrumentos de avaliação do ambiente de aprendizagem da sala de aula: uma revisão da literatura [Evaluation instruments of the classroom learning environment: a review of the literature]. Ensaio Pesquisa em Educação em Ciências (Belo Horizonte), 10(1), 137-154. https://dx.doi.org/10.1590/1983-21172008100109

[34] Soares, J. F., Alves, M. T. G., \& Oliveira, R. M. (2001). O efeito de 248 escolas de nível médio no vestibular da UFMG nos anos de 1998, 1999 e 2000 [The effect of 248 secondary schools in the UFMG entrance exam in the years 1998, 1999 and 2000]. Estudos em Avaliação Educacional, n. 24, p. 69-117, Jul-Dez.

[35] Mortimer, E. F. (2000). Linguagem e formação de conceitos no ensino de ciências [Language and concept formation in science teaching]. Belo Horizonte: Ed. UFMG, 383 p.

[36] Nascimento, S. S. (2002). A dinâmica discursiva em situações experimentais em espaços escolares e não escolares [The discursive dynamics in experimental situations in school and non-school spaces]. Research Report. Pro Rectory Research. UFMG.

[37] Villani, C. E. P.(2002). As práticas discursivas argumentativas de alunos do ensino médio no laboratório didático de física [The argumentative discursive practices of high school students in the didactic laboratory of physics]. Dissertation (Master in Education) - Faculty of Education, Federal University of Minas Gerais, Belo Horizonte.

[38] Cirino, S. D., Eiterer, C. L., \& Guimarães, E. J. (2004). Laboratório de Produção de Material Didático [Laboratory of Didactic Material Production]. In: XII Encontro Nacional de Didática e Prática de Ensino, Curitiba. v.1. p. 7887-7896

[39] Fraser, B. J. (2002). Learning environments research: yesterday, today and tomorrow. In: Goh, S. C.; Khine, M. S.
(Eds.) Studies in educational learning environments: an international perspective. River Edge, NJ: World Scientific, 2002. p. 1-25.

[40] Waldrip, B. G., \& Fisher, D. L. (2000) The Development and Validation of a Learning Environment Questionnaire Using Both Quantitative and Qualitative Methods. Journal of Classroom Interaction, v. 35, n. 2, p. 25-37.

[41] Stodolsky, S. (1984) Teacher evaluation: The limits of looking. Educational Researcher, 13, p.11-18.

[42] Walberg, H. J., \& Haertel, G. D. (1980). Validity and use of educational environment assessments. Studies in Educational Evaluation, 6, p. 225-238.

[43] Vergara, S. C. (2005). Métodos de pesquisa em administração [Methods of research in administration]. São Paulo: Atlas.

[44] Bardin, L. (2004). Análise de conteúdo [Content analysis]. Lisboa: Edições 70.

[45] Bauer, M. W., \& Gaskell, G. (2002). Pesquisa qualitativa com texto, imagem e som [Qualitative research with text, image, and sound]. Translated by Pedrinho A. Guareschi. Petrópolis: Vozes.

[46] Basílio, M. P. (2007). O Desafio da Formação do Policial Militar do Estado do Rio de Janeiro: Utopia ou Realidade Possível? [The Challenge of Military Police Training in the State of Rio de Janeiro: Utopia or Real Possibility?]. Dissertation of Masters in Public Administration Program, presented at Escola Brasileira de Administração Pública e de Empresas (EBAPE), Fundação Getúlio Vargas, Rio de Janeiro.

[47] Basílio, M. P. (2009). A diagnose do processo de formação dos operadores de segurança pública do estado do Rio de Janeiro: a perspectiva do soldado policial militar. [The diagnosis of the training process of public safety operators in the state of Rio de Janeiro: the perspective of the military police soldier]. Revista Alcance, 16(3), 358-374.

[48] Basilio, M. P. (2010). O Desafio da Formação do Policial Militar do Estado do Rio de Janeiro: Entre o Modelo Reativo e o Contingencial. [The Challenge of Training of the Military Police of the State of Rio de Janeiro: Between the Reactive and the Contingency Model]. Administración y Desarrollo, 38(52), 71-96.

[49] Basilio, M. P., \& Riccio, V. (2008). A gestão de pessoas como fator estratégico para a implementação de políticas públicas: o Caso do Treinamento Policial no Estado do Rio de Janeiro. [ The management of people as a strategic factor for the implementation of public policies: the Case of Police Training in the State of Rio de Janeiro]. INTERFACE, 5(2), 14-31.

[50] Tribunal de Contas do Estado do Rio de Janeiro. (2006). O investimento público e a efetividade das ações estatais na segurança [Public investment and the effectiveness of state actions in security]. Fundação Getúlio Vargas, Rio de Janeiro. Retrieved from http://www.tce.rj.gov.br/documents/10180/79337/Seguran $\% \mathrm{C} 3 \% \mathrm{~A} 7 \mathrm{a}$ 